\title{
運動負荷による血中凝固・線溶系因子の変動
}

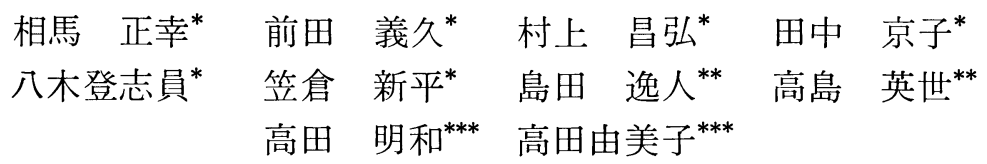

\section{Changes of exercise induced coagulation and fibrinolysis factors}

\author{
Masayuki SOMA*, Yoshihisa MAEDA*, Masahiro MURAKAMI*, \\ Kyoko TANAKA*, Toshikazu YAGI*, Shinpei KSSAKURA*, \\ Hayato SHIMADA**, Eise TAKASHIMA**, \\ Akikazu TAKADA*** and Yumiko TAKADA***
}

Key words: exercise, plasminogen activator, factor VIII, protein C, age-related decrease of PA activity

This study is desinged to investigate exercise-induced change of coagulation and fibrinolysis systems. The plasma levels of both the fibrinolytic factors including tissue type plasminogen activator ( $\mathrm{t}-\mathrm{PA}$ ) antigen urokinase-type plasminogen activator ( $\mathrm{u}-\mathrm{PA}$ ) antigen, plasminogen activator (PA) activity and plasmin $-\alpha_{2}$ plasmin inhibitor (plm- $\left.\alpha_{2} \mathrm{PI}\right)$ complex, and the coagulation factors including factor VIII related antigen (VIII R: Ag), factor VIII activity (VIII: C) and protein C (PC) antigen were measured before exercise and immediately, 15 min, $30 \mathrm{~min}$ and $60 \mathrm{~min}$ after exercise on treadmill. The levels of VIII R: Ag and VIII: $\mathrm{C}$ rose slightly after exercise, but $\mathrm{PC}$ antigen did not change. The levels of t-PA antigen, PA activity and plm- $\alpha_{2}$ PI complex elevated immediately after exercise and then decreased gradually. The levels of both t-PA antigen and PA activity returned to the control levels $60 \mathrm{~min}$ after exercise. In contrast, the level of u-PA antigen was not affected by exercise. These data suggest that the exercise-induced elevation of plasma PA activity may be caused

* 神戸市立中央市民病院臨床病理科 [干650 神戸市中央区港島中町 4-6], Department of Clinical Pathology, Kobe City General Hospital, kobe, Japan.

** 同 産婦人科, Department of Obstetrics and Gynecology, Kobe City General Hospital

*** 浜松医科大学第 2 生理学教室, Department of Physiology, Hamamatsu University School of Medicine, Shizuoka, Japan. 受付 : 1988. 4. 25. 受理 : 1988. 8. 23. 
by t-PA but not by u-PA.

The degree of elevation of t-PA and PA activity in the plasma after exercise was lower in old aged group as comparied with that in young aged group.

\section{緒言}

運動に伴ら凝固・線溶系の変動に関する研究 は臨床病理学的見地からも重要である122). 本テ ーマに捈いて，古くは半世紀以前に Biggs $ら^{3)}$ が運動にともない線溶系の活性化が生じると報 告して以来, 運動に伴う凝固線溶系の変動に関 し現在までさまざまな研究成果が報告されてい $3^{4) 576)}$. さらにこの線溶活性化の原因追及も成 されて呿り，運動に伴う線溶活性㐫進が，血管 壁由来の外因性 tissue-type plasminogen activator (t-PA) の増加による可能性が強く示唆7) されている.

今回われわれは treadmill を用いた運動負荷 を行い, 運動前後での血中 t-PA antigen 量, euglobulin fraction 中の plasminogen activator activity(PA activity), urokinase-type plasminogen activator (u-PA) antigen, plasmin- $\alpha_{2}$ plasmin inhibitor (plm- $\alpha_{2} \mathrm{PI}$ ) complex, factor VIII activity (VIII: C), factor VIII related antigen (VIII R: Ag), および protein C(PC) antigen の測定を行い, 運動に伴う線溶活性え 進が血中 t-PA もしくは u-PA の何れの増加に 起因するか，执よび t-PA 同様血管内皮細胞由 来因子である VIII R：Ag の運動に伴う血中動
態についても検討を行い, 運動に伴う線溶系活 性化機序执よび血管内皮細胞由来因子と運動々 の関係を考察したので報告する。

\section{I. 材料および方法}

\section{1. 対象 - 運動負荷方法}

測定対象は当院男性 職 員 14 例（平均年齿 $34.3 \pm 8.0$ 歳) とし, 運動負荷は Bruce 法 treadmill にて実施した。負荷量は対象個人の最大心 拍数の $85 \%$ target とし, treadmill 稼働後 target に至った後 1 分間負荷を継続させて運動 を終了した。採血は運動前に 1 時間安静にした 時点, 負荷直後および負荷後 $15,30,60$ 分後の 5 点で行った，血液は $3.13 \%$ クエン酸血とし， 血漿分離後用時までー $80^{\circ} \mathrm{C}$ にて凍結保存した。

\section{2. 測定方法}

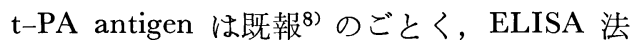
にて行い, u-PA antigen は抗 HMW-uPA ポ リクローナル抗体を用いた ELISA 法にて行っ た. PA activityは euglobulin fraction を用いて 実施した ${ }^{9)}$. VIIIR：Ag はへキスト社製の抗ヒ トAHG 抗血清を用いたローレル法, VIII：C は DADE 社製の 欠乏血漿を用いた 1 段法にて 行い, PC antigen はホモジニアス EIA 法 ${ }^{10)} に$ よった. plasmin- $\alpha_{2}$ plasmin inhibitor complex

Table 1 Exercise-induced changes of coagulation and fibrinolysis factors.

\begin{tabular}{lc|c|c|c|c|c}
\hline & & \multirow{2}{*}{ before } & \multicolumn{4}{|c}{ after exercise (min) } \\
\cline { 3 - 7 } & & & 0 & 15 & 30 & 60 \\
\hline t-PA antigen & $(\mathrm{ng} / \mathrm{m} l)$ & $4.12 \pm 0.58$ & $6.33 \pm 0.78^{*}$ & $5.15 \pm 0.70$ & $5.04 \pm 0.70$ & $4.14 \pm 0.54$ \\
u-PA antigen & $(\mathrm{IU} / \mathrm{m} l)$ & 0.0934 & 0.0986 & 0.0920 & 0.8886 & 0.0783 \\
PA activity & $(\mathrm{IU} / \mathrm{m} l)$ & $4.07 \pm 0.23$ & $4.96 \pm 0.24^{*}$ & $4.42 \pm 0.21$ & $4.09 \pm 0.20$ & $4.29 \pm 0.23$ \\
VIII R: Ag & $(\%)$ & $76.1 \pm 5.5$ & $86.4 \pm 6.8$ & $83.6 \pm 6.2$ & $82.9 \pm 6.2$ & $83.4 \pm 6.6$ \\
VIII : C & $(\%)$ & $101.1 \pm 15.0$ & $110.8 \pm 13.7$ & $110.0 \pm 14.1$ & $101.5 \pm 13.7$ & $102.0 \pm 13.4$ \\
PC antigen & $(\%)$ & $95.4 \pm 4.5$ & $96.0 \pm 4.2$ & $91.7 \pm 3.4$ & $91.3 \pm 3.9$ & $94.8 \pm 4.5$ \\
\hline
\end{tabular}




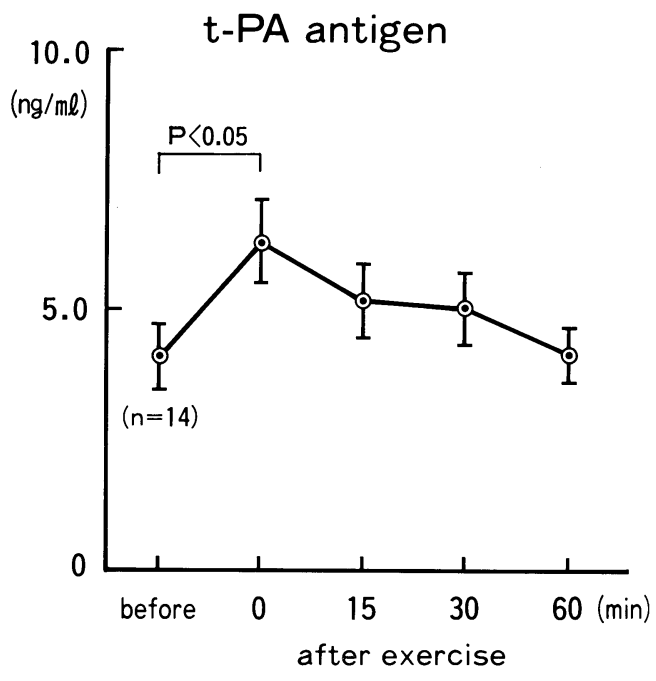

Fig. 1 Exercise-induced changes of t-PA antigen. Each points show mean $\pm \mathrm{SE}$.

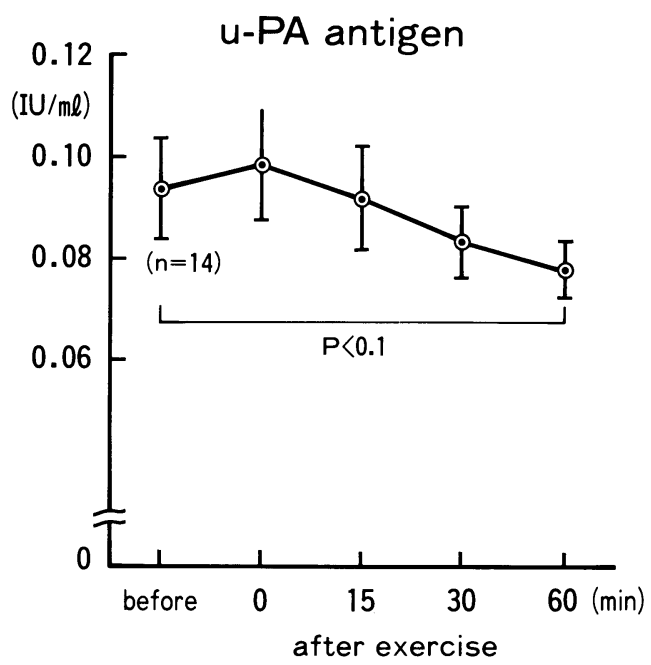

Fig. 3 Exercise-induced changes of u-PA antigen. Each points show mean $\pm \mathrm{SE}$.

測定は帝人製の EIA キット1112) にて行った。

\section{II. 成 績}

\section{1. 線溶系・凝固系の変動（表 1 ）}

運動にともない t-PA antigen は運動直後に 有意の増加 $(p<0.05)$ を示し, 以降漸減し 60 分後に運動前值に復した（図 1 )。PA activity も同様に運動直後に有意の増加 $(\mathrm{p}<0.05)$ を示 し運動 30 分後に運動前值に復した（図 2 ）。一 方 u-PA antigen は運動に伴う増加を示さず減

\section{PA activity}

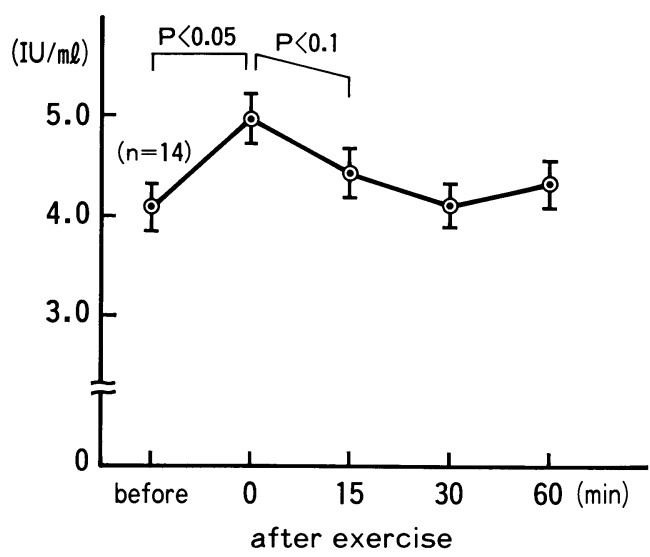

Fig. 2 Exercise-induced changes of PA activity. Each points show mean \pm SE.

VII ; RAg

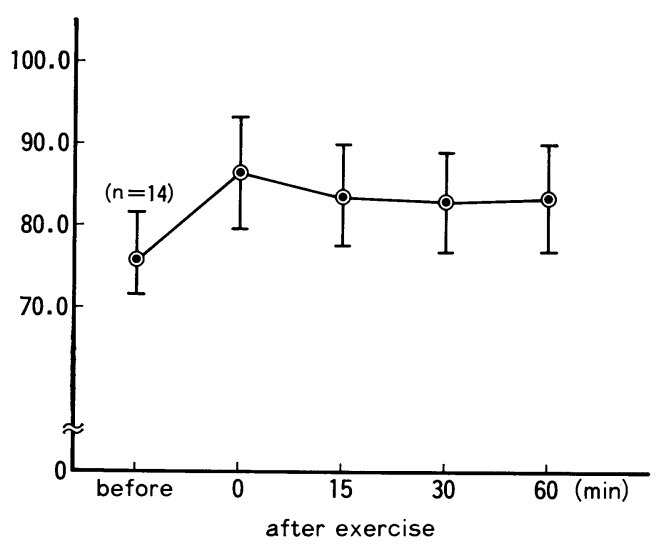

Fig. 4 Exercise-induced changes of VIII R: Ag. Each points show mean $\pm \mathrm{SE}$.

少傾向を呈した（図 3 ）.

VIII R：Ag は運動にともない軽度増加し 60 分後に扣いてもその值を維持した（図4）. VIII：C \& VIII R: Ag 同様に軽度の増加を 呈したが，30 分後に前值に復した（図 5 ). PC antigen は運動による変動を認めなかった（図 6). Plm- $\alpha_{2}$ PI complex は運動直後に軽度の増 加を示し, 15 分後に運動前值に復した（図 7 ). 
VIII ; C

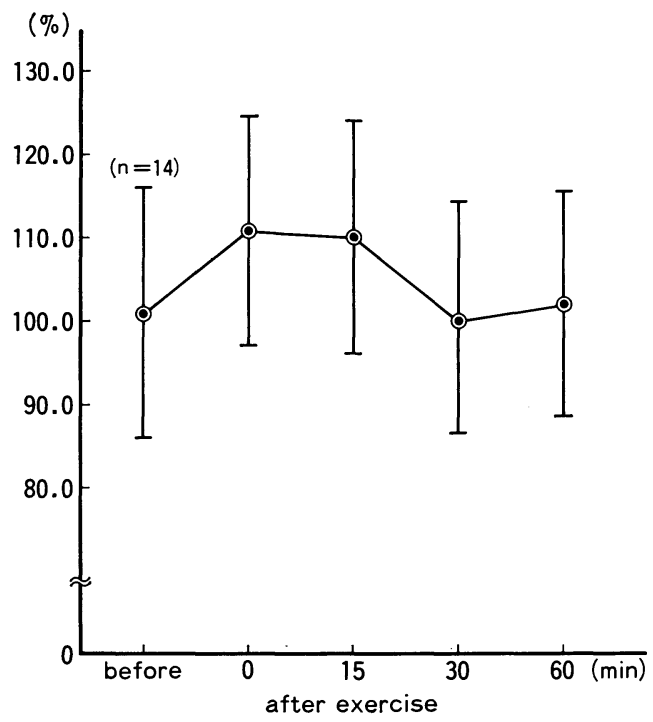

Fig. 5 Exercise-induced changes of VIII: C. Each points show mean $\pm \mathrm{SE}$.

\section{2. 線溶系変動の加齢による差異}

血中 t-PA antigen は加秢に伴い増加する ${ }^{13)}$. この影響を除去し運動に伴う線溶活性化の加齢 に伴う差異を検討するため, t-PA antigen 执よ び PA activity について，運動前值を $100 \%$ と した時の運動直後の増加率を各個人にて算出し 図 8A， Bに示した。増加率と年齢との相関は t-PA antigen では $\mathrm{r}=-0.269$, PA activity $\mathrm{r}=-0.545$ と両者とも年踚と逆相関を呈し, PA activityに执いてより著明であった。また 測定 対象を $20 ， 30 ４ 0$ 歳代の グループ別にし その mean土SD をも図 $8 \mathrm{~A}, \mathrm{~B}$ に図示した。年 代別での増加率の比較を行うと t-PA antigen, PA activity とも20，30歳代のグループに比べ 40 歳代のグループに括いて, 運動に伴う有意の 低下 $(p<0.1)$ が観察された。

\section{III. 考察}

運動に伴う凝固系の変動は, activated partial thromboplastin time (APTT), antithrombin III (AT III), $\beta$-thromboglobulin ( $\beta$-TG), fibrinopeptid A (FPA) 等がその指標 ${ }^{14)}$ とて 用いられ，また VIII 因子複合体に関しても多
PC antigen

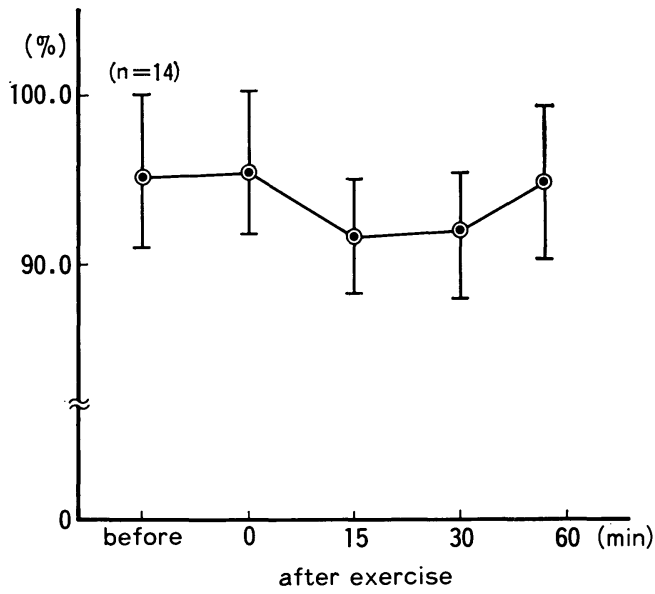

Fig. 6 Exercise-induced changes of PC antigen. Each points show mean $\pm \mathrm{SE}$.

$$
\text { P I C }
$$

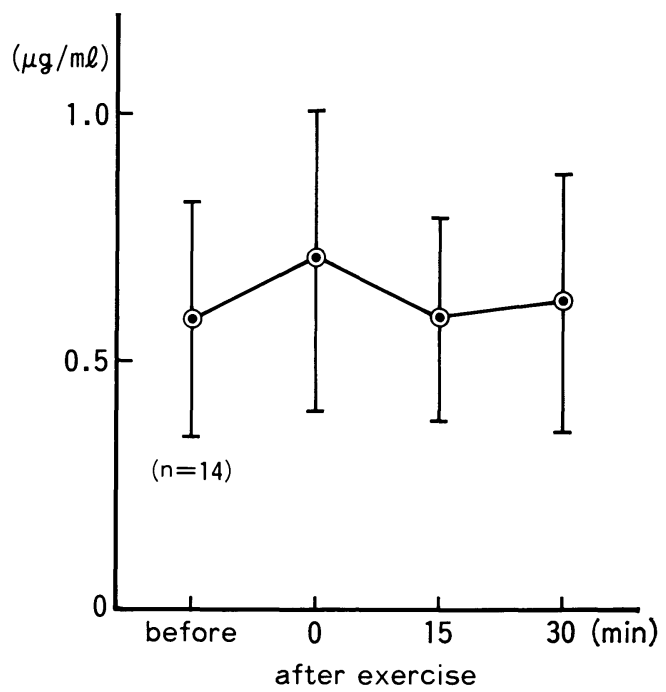

Fig. 7 Exercise-induced changes of PIC. Each points show mean $\pm \mathrm{SD}$.

くの検討結果が報告15)16)17)されている. 内因性 凝固反応に拈いて Hyers ら ${ }^{14)}$ は APTT の運動 による短縮を報告しているが Mangum ら ${ }^{18)}$ partial thromboplastin time (PTT) は不変であ るとして扣り，また Hyers ら ${ }^{14)}$ は運動 10 分後 に血中 FPA が 20〜30 倍に増加したが，血中 $\mathrm{AT} \mathrm{III，} \beta$-TG の変化は認めなかったとして 
A

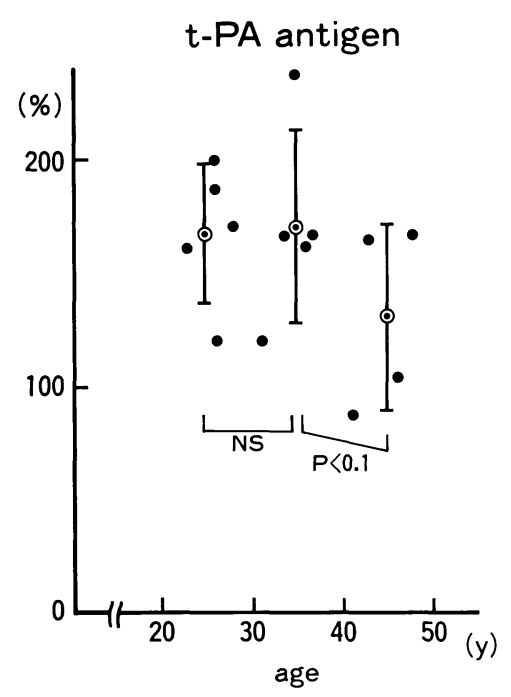

B

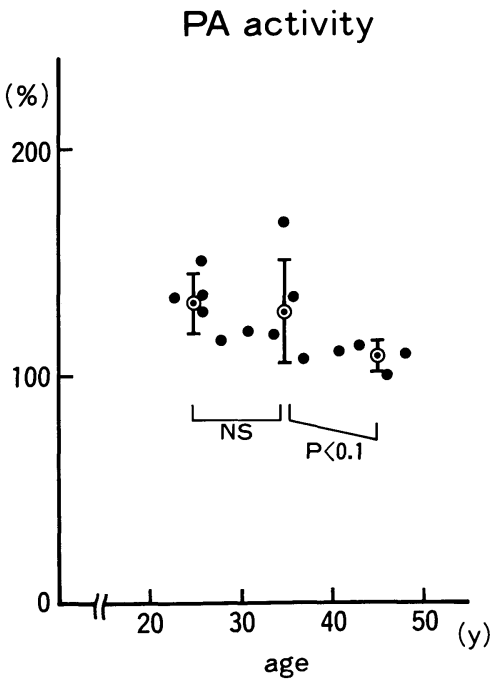

Fig. 8 Relationship between age and increasing ratio of t-PA antigen (A), and PA activity (B).

いる。また Gaur ら ${ }^{19}$ は XII 因子活性の元進 を報告している。このように運動に伴う凝固活 性の変動に関してはさまざまな結果が報告され ているが，VIII 因子の変動を観察した場合に は, 多くの研究者の結果 ${ }^{15) 16) 17) 20)}$ 亿一致が認め られる。すなわち運動にともないVIII：C, VIII R: Ag はともに上昇するとして特り，こ れは今回われわれが行った検討結果と同一であ った. しかしこれら研究者の多くはVIII R: $\mathrm{Ag}$ に比べ VIII：C・上昇がより著明である としているのに対し，われわれの観察結果にお いて運動直後に招けるVIII：C の増加率は対 照全例の平均で $109.6 \%$, VIII R: Ag では $113.5 \%$ となり, これら研究者の報告とは逆の 結果を得た。本原因については不明であるが，

VIII：C . VIII R:Ag に比べ高い増加率を 呈する報告について，その運動負荷量をみる と, Stibbe $5^{20)}$ は 3 分間の全力疾走, Bromn $ら^{16)}$ は $1 / 3$ マイルの全力疾走と, われわれが実 施した運動負荷量に比へ遙かに大きな運動負荷 を行っている.この点に関し Andrew ら ${ }^{17} は$ は, VIII 因子複合体の増加は運動量に比例すると しており，本報告から推察すると，われわれの 結果が他の研究者の結果と解離した原因とし
て，運動量が少なかった事実もその一因と考兄 られた。

さらに凝固活性充進に伴ら血中 thromboin 産生执よび血管内皮細胞膜面上の thrombomodulin の運動に伴う変化を観察するため PC antigen 測定も合わせ実施したが，運動に伴い PC antigen は核とんど変化せず，これら血中 thrombin 産生招よび thrombomodulin の動態 については PC antigen の視点からは明確な結 論を導き出せなかった.

運動に伴う線溶系の変動に関し Hyers ら ${ }^{14)}$ は fibrin plate 法, Ferguson ら ${ }^{21}$ は ELT 法を, Wiman ら 22 は 伴う線溶活性の増加を報告している。これらは われわれが観察した運動に伴う PA activity の 元進と同一の結果となった。 また $\mathrm{t}-\mathrm{PA}$ antigen 扣よび u-PA antigen の定量を行うことにより Booth ら ${ }^{23)}$ の 報告と同じく, 運動に伴う PA activity の充進は t-PA の血中濃度増加に起因 することが明らかとなった。

運動直後に血中 plm- $\alpha_{2} \mathrm{PI}$ complex 濃度の軽 度増加が観察された。本事実は, 運動に伴う PA activity の元進により 血中の plasminogen (plg) が plasmin に転換される反応が生じたた 
めと考えられた．Yamamoto ら ${ }^{24)}$ の報告では $\alpha_{2}$ PI の存在下に拈いて運動負荷を行らと, 血 中の native form である Glu-plg が Lys-plg に変換されるとしている。また Wiman ら ${ }^{22)}$ 運動量の増加にともない血中での plasmin-antiplasmin complex を認めるとしている。これら の結果はわれわれの得た成績と一致し, 運動に より亢進した PA activityにより微量の plasmin 形成が生じていると考えられた。

運動にともない血管内皮細胞由来の VIII R: $\mathrm{Ag}$, t-PA antigen の血中濃度増加は認められ, 一方 PC antigen 执よび u-PA antigen の増加 は認められなかったが, 運動に伴う凝固・線溶 系の変動は血管内皮細胞機能と密接な関係を有 する事実が示唆された。運動に伴らこれら因子 の血中濃度増加原因に関しては, Mangum ら ${ }^{18)}$ の指摘するごとく血流の増大によるものか, Wheeler らの報告 ${ }^{25)}$ にあるごとく血中 lactate が関与しているのかを明確にするのは困難であ るが, Marsh ら ${ }^{6)}$, Wheeler $5^{25)}$ の指摘するよ らに, 運動に伴らこれら内皮細胞由来因子の血 中濃度増加は, 血管内皮細胞よりの放出が原因 であると考えられた。

t-PA antigen の運動後の動向は, 運動直後に 有意の増加を示したが 15,30 分後では運動前 に比べれば増加しているものの有意なものでな く, 60 分後には運動前值に復した. 本事実より 運動刺激に対する血管内皮細胞からの t-PA の 放出は一過性のものと思われ, Marsh らの報 告6) と同様であった.

測定対象を年代別のグループにわけ各年代で の t-PA antigen 抢よび PA activity の運動に 伴う増加率を比較すると， 40 歳代では，20,30 歳代に比べ有意の低下を認めた。本事実は加歯 に伴う血栓症発症頻度増加に関し意義ある事実 の一つと考光られ, 労作性汇発症する心筋硬塞 発作とも関与している可能性があると思われ た。

\section{IV. 結 語}

運動に伴う凝固・線溶系の動態を検討するた め, treadmill を用い健常成人での VIII：C,
VIII R: Ag, PC antigen, t-PA atigen, u-PA antigen, PA activity および plm- $\alpha_{2} \mathrm{PI}$ complex の変動を検討した。

結果, VIII: C 㧊よび VIII R: Ag は運動に ともない軽度の上昇を呈するが，PC antigen は 不変であった。線溶系に执いては t-PA antigen 执よび PA activity は運動にともない有意の増 加を呈し，それぞれ60 分後扣よび 30 分後に運 動前值に復し, 平行して变化した. plm- $\alpha_{2}$ PI complex も運動直後に軽度の増加を示し, 15 分 後に運動前值に復した。しかし u-PA antigen は運動に伴う増加を認めず減少傾向を示した。

これらより運動に伴う凝固・線溶系の変動に 関し, 血管内皮細胞機能の関与の重要性が示唆 された。また運動に伴う PA activity の六進は t-PA の血中濃度増加に起因することが明らか となった.さらに運動に伴う PA activity の立 進扣よび t-PA antigen 量の増加は加龄にとも ない減少する事実を認め, これは加跉に伴う血 栓症発症頻度増加に関し意義ある事実の 1 つと 考光られ, 労作性儿発症する心筋硬塞発作とも 関与している可能性があると思われた。

本研究は中央市民病院医学振興事業費によった.

\section{文献}

1) Walker, I.D., Davidson, J.F., Hutton, I. and Lawrie, T.D.V.: Disordered "Fibrinolytic potential" in colonary heart disease. Thromb. Res., 10: 509 520, 1977.

2) Paffenbarger, R.S. Jr. and Hyde, R.T.: Exercise as protection against heart attack. N. Eng. J. Med., 302: 1026 1027, 1980.

3) Biggs, R. and Macfarlane, R.G.: Observation on fibrinolysis Experimental activity produced by exercise or adrenaline. Lancet, 1: 402 405, 1947.

4) Davis, G.L., Abilgaard, C.F., Bernauer, E.M. and Britton, M.: Fibrinolytic and hemostatic changes during and after maximal exercise in males. J. Appl Physiol, 40: 287 292, 1976.

5) Collen, D., Semeraro, J., Tricot, J.P. and Vermylen, J.: Turnover of fibrinogen, plasminogen, and prothrombin during exercise in man. J. Appl. Physiol., 42: 865 873, 1977. 
6) Marsh, N.A. and Gaffney, P.J.: Exerciseinduced fibrinolysis-fact or fiction? Thromb. Haemostas., 48: 201 203, 1982.

7) Marsh, N.A. and Gafiffney, P.J.: Some observations on the release of extrinsic and intrinsic plasminogen activators during exercise in man. Haemostasis, 9: 238 247, 1980.

8）相馬正幸, 前田義久, 上田昌典, 笠倉新平, 島 田逸人, 高島英世, 高田明和, 高田由美子 : ELISA 法による血中 t-PA antigen 測定につ いて. 臨床病理, 39: 1027 1031, 1987.

9）相馬正幸, 村上昌弘, 前田義久, 上田昌典, 笠 倉新平, 島田逸人, 高島英世: Euglobulin fractionを用いた血漿中PA activity 測定法の検討。 臨床病理, 36: 957 961, 1988.

10）前田義久, 相馬正幸, 村上昌弘, 笠倉新平：木 モジニアス EIA 法によるProtein C 抗原の測 定と加歯に伴 万生理的変動. 臨床病理, 36:1079 〜1084, 1988.

11）青木延雄, 武永 強, 長谷川淳, 小熊 豊, 小 林紀夫, 坂田洋一, 藤巻道男, 池松正次郎, 緇 荘和子, 松田 保, 伊藤恵子, 藤原研司, 富谷 知明, 林茂樹, 中村克巳, 飯島憲司, 鷲見芳 彦, 小池行也, 鈴木英明, 細田健治 : EIA 法に よる $\alpha_{2} \mathrm{PI}(\mathrm{TD}-80)$ 扣よび $\alpha_{2} \mathrm{PI}$ プラスミン 複合体（TD-80 C) 測定キットの基礎的検討. 臨床病理, 35：1275 1281, 1987.

12）高橋芳右, 滝沢慎一郎, 花野政晴, 帯刀 亘, 小池 正, 笹川康夫, 水戸将郎, 和田研, 柴 田昭：血漿プラスミン $-\alpha_{2}$ プラスミンィンヒ ビター複合体による線溶立進状態の評価：播種 性血管内凝固症候群, 血栓性血小板減少性紫斑 病, 一次線溶艺進扎よび線溶療法での検討。血 液と脈管，19：82～92，1988.

13）相馬正幸, 前田義久, 上田昌典, 笠倉新平, 島 田逸人, 高島英世, 高田明和, 高田由美子 : 加 齢に伴 5 線溶機能の生理的変動々血栓症発症に おけるその役割。臨床血液，28：1922～1927, 1987.

14) Hyers, T.M., Martin, B.J., Pratt, D.S., Dreisin, R.B. and Franks, J.J.: Enhanced thrombin and plasmin with exericse in man. J. Appl. Physiol.,48: 821 825, 1980.

15) Prentice, C.R.M., Forbes, C.D. and Smith, S.M.: Rise of factor VIII after exercise and adrenaline infusion, measured by immunological techniques. Thromb. Res., 1: 493 506, 1972.

16) Brown, J.E., Baugh, R.F. and Hougre, C.: Effect of exercise on the factor VIII complex: a correlation of the von Willebrand antigen and factor VIII coagulant antigen increase. Thromb. Res., 15: 61 67, 1979.

17) Andrew, M., Carter, C., O Brodovich, H. and Heigenhauser, G.: Increase in factor VIII complex and fibrinolytic activity are dependent on exercise intensity. J. Appl. Physiol., 60: 1917 1922, 1986.

18) Mangum, M.E., Haymes, E.M. and Lipner, H.: Coagulation and fibrinolytic responses to exercise and cold exposure. Aviat. Space Environ. Med., 55: 291 295, 1984.

19) Gauer, S., Datta, S., Bhargava, R.P. and Rao, S.V.: Effect of exhaustive ergometric exercise on blood coagulation, platelet adhesiveness and fibrinolytic activity in untrained young men and woman. Ind. J. Physiol. Pharmac., 26: 65 68, 1982.

20) Stibbe, J.: Effect of exercise on F VIII-complex: Propotional increase of ristocetin cofactor (von Willebrand factor) and F VIII-AHF. Thromb. Res., 10: 163 168, 1977.

21) Ferguson, E.W., Barr, C.F. and Brenier, L.L.: Fibrinogenolysis and fibrinolysis with strenuous exercise. J. Appl. Physiol., 47: 1157 1161, 1979.

22) Wiman, B., Mellbring, G. and Ranby, M.: Plasminogen activator release venous stasis and exercise as determined by a new specific assay. Clin. Chem. Acta, 127: 279 288, 1983.

23) Booth, N.A., Walker, E., Manghen, R. and Bennett, B.: Plasminogen activator in normal subjects after exercisse and venous occulusion: t-PA circulates as complexes with $\mathrm{Cl}$-inhibitor and PAI-1. Blood, 69: 1600-1604, 1987.

24) Yamamoto, J., Okamoto, M. and Kawasaki,H.: Production of Lys-plasminogen in urokinaseactivated human plasma. Acta Haematol. Jpn., 49: 131 135, 1986.

25) Wheeler, M.E., Dabis, G.L., Gillespie, W.J. and Bern, M.M.: Physiological changes in hemostasis associated with acute exercise. J. Appl. Physiol., 60: 986 990, 1986. 